\title{
Factors Affecting Financial Leverage: The Case of Vietnam Firms
}

\author{
Chi Dieu Thi NGUYEN ${ }^{1}$, Hong Thuy Thi DANG ${ }^{2}$, Nghi Huu PHAN ${ }^{3}$, Trang Thuy Thi NGUYEN ${ }^{4}$
}

Received: August 01, 2020 Revised: October 05, 2020 Accepted: October 15, 2020

\begin{abstract}
The purpose of the study is to find the factors that influence the financial leverage of Vietnam firms. The dependent variable is the financial leverage and the independent variables are firm size, asset structure, liquidity, growth opportunities, profitability, and firm age. The data are collected from Vietnam firms' annual financial reports in the period from 2010 to 2019. The study uses a sample of 448 Vietnam listed firms in the period. We also employ a panel regression model with pooled OLS and fixed effect to analyze the firms' financial data. The results of the model showed that financial leverage (FL) has a negative relationship with some factors such as asset structure (AS), liquidity (LQ), growth opportunities (GRW), profitability (ROA), and firm age (AGE) in the fixed effect regression. It means that when liquidity, profitability, and firm age increase, firms' financial leverage will decrease. While firms' financial leverage has still a positive relationship with the firm size (SIZE) in the model. As a result, when firm size increases, financial leverage will increase, too. The results showed that models are fit for the research and can be used to predict future findings. It is also useful for enterprises, financial advisors, investors, as well as the financial managers.
\end{abstract}

Keywords: Capital Structure, Financial Leverage, Financial Structure, Vietnam Firms

JEL Classification Code: C58, G30, G32

\section{Introduction}

One of the toughest challenges that business firms face is the choice of financial structure. Financial structure decision is important because it affects the financial performance of the firms. Abor (2005) defined financial structure or capital structure as a specific mix of debt and equity that a firm uses to finance its operations. Although firms have many options of capital structures, they tend to rely on borrowings from financial institutions.

Modigliani and Miller (1958) first deeply studied the issues on capital structure. And since their study, some theories

${ }^{1}$ First Author and Corresponding Author. Lecturer, School of Banking and Finance, National Economics University, Vietnam [Postal Address: No. 910, A1 Tower, 207 Giai Phong, Hai Ba Trung, Hanoi, 100000, Vietnam] Email: chintd@neu.edu.vn

${ }^{2}$ Lecturer, School of Trade and International Economics, National Economics University, Vietnam. Email: hong.dangtt@neu.edu.vn ${ }^{3}$ Lecturer, School of Banking and Finance, National Economics University, Vietnam. Email: nghiph@neu.edu.vn

${ }^{4}$ Lecturer, Faculty of Mathematics Economics, National Economics University, Vietnam. Email: thuytrang@neu.edu.vn

(c) Copyright: The Author(s)

This is an Open Access article distributed under the terms of the Creative Commons Attribution Non-Commercial License (https://creativecommons.org/licenses/by-nc/4.0/) which permits unrestricted non-commercial use, distribution, and reproduction in any medium, provided the original work is properly cited. including the trade-off theory of Modigliani and Miller (1963) as well as Miller (1977), agency theory of Jensen and Meckling (1976), signaling theory of Ross (1977), pecking order theory of Myers and Majluf (1984) and free cash flows theory of Jensen (1986) have evolved. Despite, each theory having a different opinion, indicates the importance of capital structure on firms' performance as well as firms' value. The general result from the various capital structure studies is that the combination of financial leverage related costs and the tax advantage of debt produces an optimal capital structure below 100\% debt financing. Therefore, the tax advantage is traded against the likelihood of incurring bankruptcy costs. As a result, there have been many studies about financial leverage as well as determinants of this issue in developed and developing countries. However, there is a lot of difference in views, results, and conclusions of studies.

Some studies of Bevan and Danbolt (2002), Akhtar and Oliver (2009), Serghiescua and Văidean (2014) in developed countries, and Booth, Aivazian, Demirguc-Kunt, and Maksimovic (2001), Chen (2003), Tran and Tran (2008), Nguyen, Dang, Luong, and Nguyen (2019), Nguyen, Bui, and Pham (2019), Dao and Ta (2020), Nguyen and Nguyen (2020) in developing countries indicated that there is a difference in the determinant of capital structure influence on firms' performance. While studying this issue, it was done in context of Vietnam being a developing country, so this is 
a market with a lot of investment potential. As a result, it gets attention for investors and managers to rethink the effect of determinants of using debt on their firms. Some researches on this issue such as Dao and Lai (2018), Vu, Doan, and Le (2020) are still in disagreement about the impact of factors on firms' financial leverage as well as the importance of these factors on financial leverage.

The purpose of this study is to synthesize the classical and modern theories of financial leverage, to identify the factors specific to a firm that have a significant impact on its financing decisions. This study will focus on analyzing the impact of factors on the financial leverage of 448 Vietnam listed firms by using the panel data models from 2010 to 2019. This study is different from others because it considers and deeply analyzes firms' specific factors that still remains unclear in Vietnam.

The paper includes 5 sections in which section 1 is the introduction part. The rest of the paper is organized as follows: Section 2 provides a background of literature, relating to financial leverage and determinants of financial leverage. Section 3 presents the methodology used, more specifically, the selected data, the way of defining and measuring the explanatory variables as well as research hypotheses, and the econometric models applied. Section 4 discusses and analyses the empirical results. Conclusions are offered in the final section.

\section{Literature Review}

\subsection{Fundamental Theories of Firm Financing}

\subsubsection{Modigliani-Miller Theory}

Modigliani and Miller were the first to set up a theory of optimal capital structure in 1958. In the theory, two authors proved that, in a world of no taxes, the firm's value is unaffected by the debt to equity ratio. However, the theory is faced with many criticisms from researchers because the business environment always has barriers, transaction costs, taxes, and expectations. Moreover, the theory of Modigliani and Miller (1958) also did not indicate how a firm can finance its assets between debt and equity to gain an optimal capital structure as well as bring benefits to the firms. Until 1963, Modigliani and Miller reviewed their theory and added the tax factor. In 1977, they continued dividing the tax factor into firm tax and individual tax in their theory. However, according to this theory, an optimum capital structure is subject to tax advantages of debt and that is why firms should have a capital structure almost totally composed of debt. But in the real world, firms generally assume to use moderate amounts of debt due to its high bankruptcy costs in case firms cannot control debt source. Although the theory of Modigliani and Miller does not take into consideration bankruptcy costs, and other costs of the agent as well as it does not distinguish between natural and legal persons when referring to the lending process, Modigliani and Miller's theorem is considered as the most important reference of capital structure. After Modigliani and Miller's theorem, three fundamental theorems have been developed on the capital structure including Static Trade-off Theory, Pecking Order Theory, and Agency Cost Theory.

\subsubsection{Trade-Off Theory}

Trade-off theory was suggested by Myers and Majluf (1984) in which it emphasized a balance between tax-saving arising from debt, a decrease in agent cost, bankruptcy, and financial distress costs. Hence, the theory stated that firms with safe, tangible assets and plenty of taxable income to shield should have high target debt ratios. The theory also explained the difference in capital structure among sectors, however, it could not explain why profitable firms within the industry have lower debt ratios.

\subsubsection{Pecking Order}

The theory was studied by Myers and Majluf (1984). However, instead of only indicating firm taxes and financial distress into the Modigliani and Miller theory, the key assumption of the pecking order theory is asymmetric information. Asymmetric information is that managers know more than investors therefore they will provide a signal to investors about the prospects of the firm. Moreover, the Pecking Order theory also considered that internal financing is preferred over external financing, and if external finance is required, firms should issue debt first and should issue equity as a last source. Besides, the pecking order explained why profitable firms have low debt ratios. This happens not because these firms have low target debt ratios, but because they do not need to obtain external financing. Thus, unlike the trade-off theory, the pecking order theory can explain differences in capital structures within sectors.

\subsubsection{Agency Cost Theory}

In 1976, Jensen and Meckling (1976) suggested the agency theory describes the relationship between principals and agents, for example, the association between shareholders and executives as well as the connection between bondholders and shareholders. The theory stemmed from problems caused by different goals of between principals and agents, between shareholders and managers, and between debt holders and stockholders. When managers would not act in the best interests of their existing shareholders, they tend to wastefree cash flow and bad investments. When the conflicts of interest occur, it has a propensity to respond to agency costs, which are the costs of resolving conflicts between the 
principals and agents and aligning interests of the two groups. The theory implies that the appropriate combination of debt and equity capital could help to solve the conflicts of interest and reduce agency costs. Firms that have a strict control by the major shareholders will have fewer agency costs and will be more efficiently managed, hence, debt is less valuable as a means of control.

\subsection{Empirical Review}

Since the Modigliani and Miller theory in 1958, there have been many empirical studies related to capital structure because decisions on capital structure are important not only for the need to maximize profits but also for their impact on the competitiveness of the firms. Selecting and using an appropriate capital structure is one of the factors that contributes to the success of the financial strategy of the firms (Kajananthan, 2012). Handoo and Sharma (2014) studied the impact of seven factors on the capital structure of Indian firms. The paper used a data set of 870 listed firms from the period of 2001 - 2010. Findings indicated that factors like profitability, growth, asset tangibility, size, cost of debt, tax rate, and debt serving capacity have significant influences on the capital structure as well as financial leverage of the Indian firms. Or Keister (2004) analyzed the determinants of the financial leverage of the Chinese firms. The results also indicated that size, tangibility, and profitability influence firms' financial leverage. Moreover, the study of Chen (2003) investigated the determinants of the capital structure of 972 listed firms on the Shanghai Stock Exchange. He found that profitability is negatively related to financial leverage at a highly significant level. Besides, the size and risk of the firms are positively related to the debt ratio. The firms' age is positively related to financial leverage. And, firms with higher institutional shareholdings tend to avoid using debt financing. Chen and Strange (2005) also indicated that liquidity, profitability, assets structure, and asset size are significant factors which impacts firms' financial leverage. Bhabra, Liu, and Tirtiroglu (2008) considered some different factors such as the firm size and the growth opportunities.

Hossain (2012) studied 39 listed firms on the Dhaka Stock Exchange from 2003 to 2007 . The study indicated that profitability, tangibility, liquidity, and managerial ownership have a significant and negative impact on financial leverage. Besides, a positive and significant impact of growth opportunity and non-debt tax shield on leverage has been found. Five factors influencing financial leverage in Vatavu (2015) showed that profitability and liquidity ratios have a negative impact on the total debt ratio of Romanian firms. On the other hand, the size of firms and their asset turnover have a positive correlation with financial leverage. And, profitability has the most influence on the firms' financial leverage.
To summarize, recent financial leverage studies have shown many different findings that prove the impact of many factors on firms' financial leverage. Basing on theories and empirical studies, this study also attempts to measure the impact of firms' specific determinants on the financial leverage of 448 Vietnam listed firms using total debt (TD) ratio as the financial leverage variable. The firm's specific determinants used in this empirical study are firm size (SIZE), asset structure (AS), liquidity (LQ), growth opportunity (GRW), profitability (ROA), and firm age (AGE).

\section{Research Methodology}

\subsection{Research Data}

To examine the impact of firms' specific determinants on Vietnam firms' financial leverage, we collected data of 448 non - financial listed firms for a period of 10 years (2010 2019). The banks and the other financial institutions were kept out of this study because of their specific financial activities. Besides, the study used a strongly balanced panel data from annual financial statement data with 4480 observations.

\subsection{Variables and Hypotheses}

Frank and Goyal (2009) used the financial leverage variable like total debt to total assets and total debt to equity. Pandey (2002) used only the ratio of total debt to total assets at book value to identify the firms' financial leverage. In some of the other studies such as by Sheikh and Wang (2011), used the total liabilities ratio as the main measure of financial leverage. Frank and Goyal (2009) still suggested the use of the market value of debt as a suitable measurement for financial leverage as it reflects in a better way the current position and future position of the firms. However, there are many other studies using accounting measures to decide financial leverage like studies of Chen (2003), Keister (2004), Bhabra, Liu, and Tirtiroglu (2008), Frank and Goyal (2009), Hossain (2012), Dao and Lai (2018). As a result, this study used book value instead of market value to assess the impact of determinants on firms' financial leverage. The study has used the following measure as a proxy of firms' financial leverage.

$$
\mathrm{TD}=\frac{\text { Total Debts }}{\text { Total Assets }}
$$

\section{Firm size}

Some findings indicated that there is a positive relation between the firm size and the financial leverage. While some others considered that there is a negative relation. Some other findings even suggested it as a statistically insignificant relationship. According to Rajan and Zingales (1995), Booth, Aivazian, Demirguc-Kunt, and Maksimovic (2001), firm size 
is positively correlated with firms' financial leverage. The reason can be given as the fact that larger firms can easily approach debt at lower costs than smaller firms. A study of Hossain (2012) revealed a negative relationship between firm size and financial leverage. While, findings of Dilek, Ozlem, and Ayca (2009) reported that the impact of firm size on financial leverage is insignificant. However, all these studies still used the natural logarithm of the total asset as a proxy for firm size.

\section{Asset structure}

Asset structure or tangibility is measured by the ratio of fixed assets to total assets. Many studies have proven that there is an influence of asset structure on financial leverage. Myers (1984), Bradley, Jarrell, and Kim (1984) and Daskalakis and Psillaki (2008) found that the firms with higher tangibility are often easier to access debts because of the availability of collateral. Their results showed the positive relationship between asset structure and debts. In contrast to these findings, Sheikh and Wang (2011) found that there is still a negative relationship between asset structures with debts of Pakistani firms.

\section{Liquidity}

The liquidity of a firm is measured by the ratio of total assets to short term debts at year-end. Firms with large current assets often prefer to use internal funds to finance business activities instead of using external sources. Therefore, these firms often use fewer debts, and the study results revealed that there is a negative relationship between firms' liquidity and financial leverage (Myers, 1984). It is right with the identification of the pecking order theory. However, the trade-off theory suggested that there is a positive relationship between liquidity and the ability of a firm to pay a debt obligation on time. It means that higher liquidity expresses firms having the ability to pay their debt (Ozkan, 2002).

\section{Growth opportunities}

Williamson (1988), Harris and Raviv (1991) proved that firms with growth opportunities will tend to have less debt. The study of Buferna, Bangassa, and Hodgkinson (2005) also supported this point of view. They found that growth opportunities can cause some hazard effects on firms. And, to solve the problem, firms should use their equity instead of debts. As a result, there is a negative relationship between growth opportunities and firms' debts. However, studies of Titman and Wessels (1988), Chen (2003) revealed that there is a positive relationship between growth opportunities and financial leverage. Firms with higher growth opportunities are more likely to face higher information imbalance, hence they are expected to have higher debt levels.

\section{Profitability}

Naveed, Zulfqar, and Ishfaq (2010) indicated the negative relationship between profitability and financial leverage. The study confirmed that Pakistan Insurance companies prefer to use internal financing than debts. The more profitable the firms are, the more internal financing they are going to have. These findings were also supported by the research results of Harris, and Raviv (1991), Booth, Aivazian, Demirguc-Kunt, and Maksimovic (2001), and Kajananthan (2012). On the other hand, Dilek, Ozlem, and Ayca (2009) found that there is a positive relationship between profitability and debt ratios. They explained that firms with higher profitability can easily attract more debts from banks as well as from the financial market. Moreover, these firms also prefer debts in order to decrease tax charges. All studies measure profitability as earnings after interest and taxes divided by total assets.

Table 1: Variables and hypotheses

\begin{tabular}{|c|c|c|c|c|}
\hline Indicators & Variables & Accounting Indicator & Measurement & Hypotheses \\
\hline Financial leverage & TD & Total debt ratio & Total debts/Total assets & \\
\hline Firm size & SIZE & Firm size & Log of total assets & + \\
\hline Asset structure & AS & Tangible asset & Fixed assets/Total assets & - \\
\hline Liquidity & LQ & Liquidity ratio & $\begin{array}{l}\text { Total assets/Short - term debts at } \\
\text { year end }\end{array}$ & - \\
\hline Growth opportunities & GRW & $\begin{array}{l}\text { Percentage change in } \\
\text { total assets }\end{array}$ & $\begin{array}{l}\text { (Ending total assets in current } \\
\text { year - Ending total assets in } \\
\text { previous year)/Ending total } \\
\text { assets in previous year }\end{array}$ & - \\
\hline Profitability & ROA & Return on assets & $\begin{array}{l}\text { Earnings after interest and taxes } \\
\text { /total assets }\end{array}$ & - \\
\hline Firm age & AGE & Performance age & Years of firms' performance & - \\
\hline
\end{tabular}




\section{Firm age}

Myers (2001), Akhtar and Oliver (2009) found that firm age has a significantly positive correlation with both shortterm debt ratio and long-term debt ratio. The findings revealed that firm age is a measure of a firms' reputation. As a result, the longer a firm does business, the easier it approaches debts. Contrary to this point of view, Abor (2005) indicated a negative relationship between firm age and total debts when he did a comparative study on the listed and unlisted firms in Ghana.

To test the hypotheses, the study used a panel regression model, in which the dependent variable is the total debt ratio as firms' financial leverage, the independent variables are firm size, asset structure, liquidity, growth opportunities, profitability, and firm age.

\subsection{Model Specification}

Panel data involves the pooling of observations on a crosssection of units over several periods. The panel data approach is more useful than either cross-section or time-series data alone. Besides, Panel data can also control for heterogeneity due to hidden factors in time series or cross-sectional estimations, leading to biased results (Baltagi, 1995). Thus, the study implies static data modeling using pooled OLS and fixed effect regression as estimation techniques for firms' financial leverage. The study used the Stata (version 14) computer software to test, analyze, and find the research findings. The entire variables for this study are based on the book value in line with the argument by Myers (1984) that book values are good proxies for the value of assets. We modeled our study as follows:

$$
\begin{aligned}
\mathrm{TD} & =\beta_{0}+\beta_{1} \mathrm{SIZE}_{\mathrm{it}}+\beta_{2} \mathrm{AS}_{\mathrm{it}}+\beta_{3} \mathrm{LQ}_{\mathrm{it}}+\beta_{4} \mathrm{GRW}_{\mathrm{it}} \\
& +\beta_{5} \mathrm{ROA}_{\mathrm{it}}+\beta_{6} \mathrm{AGE}_{\mathrm{it}}+\varepsilon_{\mathrm{it}}
\end{aligned}
$$

Equation 2 is estimated using the pooled OLS method. This method assumes that intercept $(\beta 0)$ is the same for all the cross-sections (Asteriou \& Hall, 2007), in our study all listed firms. However, the firms sampled for this study may be heterogeneous and can have different intercepts due to different management styles, industries, and markets they serve (Haron, 2014). Therefore, the fixed effect method of estimation is considered to be used. The equation is modified as under:

$$
\begin{aligned}
\mathrm{TD} & =\beta_{0 \mathrm{i}}+\beta_{1} \mathrm{SIZE}_{\mathrm{it}}+\beta_{2} \mathrm{AS}_{\mathrm{it}}+\beta_{3} \mathrm{LQ}_{\mathrm{it}}+\beta_{4} \mathrm{GRW}_{\mathrm{it}} \\
& +\beta_{5} \mathrm{ROA}_{\mathrm{it}}+\beta_{6} \mathrm{AGE}_{\mathrm{it}}+\varepsilon_{\mathrm{it}}
\end{aligned}
$$

Equation (3) is added subscript $i$ to intercept $\beta_{0}$ to account for the different intercepts for all firms. We use Hausman (1978) test to choose suitable estimation models.

\section{Empirical Results and Discussion}

Table 2 presents descriptive statistics of 448 Vietnam listed firms. Financial information was collected from annual business reports in the period of $2010-2019$. The findings showed that the average of total debts to total assets (TD) for the sample is $53.39 \%$. The standard deviation of TD is $59.21 \%$, minimum value of TD is $0.20 \%$, and the maximum value is $1606.9 \%$.

Besides, the mean value of size is $13.49 \%$, the standard deviation is $1.49 \%$. The minimum and maximum size is $9.21 \%$ and $19.30 \%$ respectively. Vietnam listed firms' asset structure uses $39.74 \%$ of net fixed assets in the structure of their assets on average. The maximum asset structure is $97.74 \%$ and the minimum value of the asset structure is $0.10 \%$. The liquidity ratios indicate that on average firms use current assets by 5.25 times of short-term liabilities. There is also an enormous difference among firms when the minimum and maximum value of LQ is $6 \%$ and 504.43 times. The average asset growth rate is 5.12 times with a standard deviation of 29.17 times. The average value of profitability is $4.07 \%$. The maximum profitability is $78.37 \%$ while the minimum value is $-804.84 \%$. Or, the average of firm age is 23.79 years, while the standard deviation is 14.16 years. The maximum value of the firm age is 111 years and the minimum value is 2 years. The results proved that there is an enormous difference among Vietnam listed firms in the period from 2010 to 2019. These findings can also be explained by a difference in sectors of the firms.

Table 2: Descriptive Statistics

\begin{tabular}{|l|c|c|c|c|c|c|}
\hline Variable & Observation & Unit & Mean & S.D & Minimum & Maximum \\
\hline TD & 4480 & $\%$ & 53.39 & 59.21 & 0.20 & 1606.90 \\
\hline SIZE & 4480 & $\%$ & 13.49 & 1.49 & 9.21 & 19.30 \\
\hline AS & 4480 & $\%$ & 39.74 & 23.18 & 0.10 & 97.74 \\
\hline LQ & 4480 & $\%$ & 5.25 & 17.15 & 0.06 & 504.43 \\
\hline GRW & 4480 & $\%$ & 511.89 & 2916.56 & -59.44 & 102561.3 \\
\hline ROA & 4480 & $\%$ & 4.07 & 26.26 & -804.84 & 78.37 \\
\hline AGE & 4480 & Year & 23.79 & 14.16 & 2 & 2 \\
\hline
\end{tabular}


Table 3 reports the Pearson's correlation coefficients between the variables. Asteriou and Hall (2007) stated that many researchers consider a correlation coefficient of more than 0.8 causing the problems in estimation. Considering this as the benchmark, the table shows that correlations among the independent variables are comparatively small and thus there shouldn't be the concerns for multicollinearity.

Table 4 shows the estimation results of pooled OLS and fixed effect. In two regression models for financial leverage represented by TD has an R-squared (coefficient of determination) of 0.456 and 0.662 . It tells us that Vietnam firms' financial leverage is influenced by $45.6 \%$ of selected independent variables in the pooled OLS model, and $66.2 \%$ of selected independent variables in the fixed-effect model.

Column 2 of Table 4 shows the OLS estimation results. Firm size is found to have a positive influence, and tangible asset, liquidity, growth opportunities, and profitability have a negative significant influence at $1 \%$, and $5 \%$ level of significance respectively. A positive significant relationship of firm size with firms' financial leverage supports the argument of alternative of the firm size of Booth, Aivazian,
Demirguc-Kunt, and Maksimovic (2001). A negative significant influence of tangible asset, liquidity, growth opportunities, and profitability is the same as in the findings of Myers (1984), Williamson (1988), Harris, and Raviv (1991), Buferna, Bangassa, and Hodgkinson (2005), Naveed, Zulfqar, and Ishfaq (2010), Sheikh and Wang (2011). The firm age turns out to be insignificant in this model.

Column 3 of Table 4 reports the result of the fixed effect estimator of Vietnam firms' financial leverage. Firm size has a consistently significant positive influence and tangible asset, liquidity, growth opportunities, profitability, and firm age have a negative significant impact on Vietnam firms' financial leverage. The negative significant influence of firm age is the same as in the findings of Abor (2005).

To sum up, firm size, tangible asset, liquidity, growth opportunities, profitability, and firm age appear to be significant determinants of Vietnam firms' financial leverage using fixed-effect regression. While firm age is insignificant in the pooled OLS model. Increased R-square in the fixed effect model indicates that firms' heterogeneity in terms of variables determining the level of financial leverage exists.

Table 3: Correlation Matrix

\begin{tabular}{|l|c|c|c|c|c|c|c|}
\hline & TD & SIZE & AS & LQ & GRW & ROA & AGE \\
\hline TD & 1.0000 & & & & & & \\
\hline SIZE & 0.0892 & 1.0000 & & & & & \\
\hline AS & 0.0128 & 0.1125 & 1.0000 & & & & \\
\hline LQ & -0.1128 & -0.0542 & 0.1700 & 1.0000 & & & \\
\hline GRW & -0.0043 & -0.0604 & -0.1328 & -0.0019 & 1.0000 & & \\
\hline ROA & -0.7874 & 0.054 & -0.0833 & 0.0127 & -0.0699 & 1.0000 & \\
\hline AGE & 0.0333 & 0.0132 & 0.0104 & -0.0602 & -0.0167 & 0.0080 & 1.0000 \\
\hline
\end{tabular}

Table 4: Regression Results of Pooled OLS and Fixed Effected Models

\begin{tabular}{|l|c|c|}
\hline Variables & Pooled OLS Model & Fixed Effect Model \\
\hline SIZE & $5.148^{* * *}$ & $7.561^{* * *}$ \\
\hline AS & $-0.0762^{*}$ & $-0.0156^{*}$ \\
\hline LQ & $-0.113^{* * *}$ & $-0.0745^{*}$ \\
\hline GRW & $-0.000907^{* * *}$ & $-0.000801^{* * *}$ \\
\hline ROA & $-1.777^{* * *}$ & $-1.780^{* * *}$ \\
\hline AGE & 0.0109 & $-0.608^{* * *}$ \\
\hline CONS & -5.053 & 4480 \\
\hline Observation number & 4480 & 0.662 \\
\hline R-Square & 0.456 & 0.624 \\
\hline Adjusted R - square & 0.403 & \\
\hline
\end{tabular}

Note: ${ }^{* * *},{ }^{* *}$ and ${ }^{*}$ indicates significant at $1 \%, 5 \%$ and $10 \%$ level of significance. 


\section{Conclusions}

In conclusion, this empirical study aims at understanding the effect of specific determinants on Vietnam firms' financial leverage using pooled OLS and fixed effect regressions. A balanced panel data from 2010 to 2019 of 448 Vietnam listed firms is extracted from annual firms' financial balance sheets. Results reveal that in Vietnam, firm size has a positive significant effect on firms' financial leverage in both pooled OLS and fixed effect regressions. This finding is supported by Booth, Aivazian, Demirguc- Kunt, and Maksimovic (2001), Chen (2003), or Keister (2004). Besides the reason is that larger firms can easily approach debt at lower costs than smaller firms, larger firms are diversified and hence their chances of being bankrupt are less. Therefore, the trade-off theory lends support to this finding. Besides, tangible assets, liquidity, growth opportunities, and profitability are found to be negative significant in both models. All these findings are supported by the pecking order theory of Myers and Majluf (1984). Firm age is found negatively affecting firms' financial leverage in fixed effect estimation techniques. However, the firm age is insignificant in the pooled OLS estimation technique. The findings reveal that using the firms' fixed effect technique enhances the explanatory power of the model as well as suggests that individual firms' heterogeneity matters in determining the firms' financial leverage.

This study is limited to a sample of Vietnam listed firms. Future research should investigate all Vietnam firms which are functioning in the economy. Moreover, future studies regarding the firms' financial leverage in Vietnam may consider the impact of macro factors such as GDP, Inflation, Interest rate, firm tax, and financial market environment. The studies of firms' financial leverage using dynamic modeling may be another future research area for Vietnam.

\section{References}

Abor, J. (2005). The effect of capital structure on profitability: An empirical analysis of listed firms in Ghana. Journal of Risk Finance, 6(5), 438 - 445. https://doi. org/10.1108/15265940510633505

Akhtar, S., \& Oliver, B. (2009). Determinants of capital structure for Japanese multinational and domestic corporations. International Review of Finance, 9(1-2), 1-26. https://doi.org/10.1111/j.14682443.2009.01083.x

Asteriou, D., \& Hall, S. G. (2007). Applied Econometrics: A modern approach using Eviews and Microsoft. New York, NY: Palgrave Macmillan.

Baltagi, B. H. (2005). Econometric Analysis of Panel Data (3rd ed.). Hoboken, NJ: John Wiley \& Sons.

Bevan, A. A., \& Danbolt, J. (2002). Capital structure and its determinants in the United Kingdom: A decomposition analysis.
Applied Financial Economics, 12(3), 159-170. https://doi. org/10.1080/09603100110090073

Bhabra, H., Liu, T., \& Tirtiroglu, D. (2008). Capital structure choice in a nascent market: Evidence from listed firms in China. Finance Management Journal, 37, 341-364. https://doi. org/10.1111/j.1755-053X.2008.00015.x

Booth, L., Aivazian, V., Demirguc-Kunt, A., \& Maksimovic, V. (2001). Capital structures in developing countries. Journal of Finance, 56 (1), 87-130. https://doi.org/10.1111/00221082.00320

Bradley, M., Jarrell, G. A., \& Kim, E. H. (1984). On the existence of an optimal capital structure: Theory and evidence. Journal of Finance, 39(3), 857-878. https://doi. org/10.1111/j.1540-6261.1984.tb03680.x

Chen, J. J. (2003). Determinants of capital structure of Chineselisted companies. Journal of Business Research, 57(12), 13411351. https://doi.org/10.1016/S0148-2963(03)00070-5

Chen, J., \& Strange, R. (2005). The determinants of capital structure: Evidence from Chinese listed companies. Economic Change and Restructuring, 38, 11-35. https://doi.org/10.1007/s10644005-4521-7

Dao, T. T. B., \& Lai, H. P. (2018). A Study on Optimal Capital Structure of Vietnamese Real Estate Listed Firms. Journal of Economics and Development, 20(3), 45-70. DOI: 10.33301/ JED-P-2018-20-03-04

Dao, T. T. B., \& Ta, T. D. N.(2020). A meta-analysis: Capital structure and firm performance. Journal of Economics and Development, 22(1), 111-129. DOI: 10.1108/JED-12-2019-0072

Daskalakis, N., \& Psillaki, M. (2008). Do country or firm factors explain capital structure? Evidence from SMEs in France and Greece. Applied Financial Economics, 18(2), 87-97. https://doi. org/10.1080/09603100601018864

Dilek, T., Ozlem, T., \& Ayca, T. (2009). Determinants of capital structure for Turkish firms: A panel data analysis. International Research Journal of Finance and Economics, 29, 180-187.

Frank, M. Z., \& Goyal, V. K. (2009). Capital structure decisions: Which factors are reliably important? Financial Management, 38(1), 1-37. https://doi.org/10.1111/j.1755-053X.2009.01026.x

Handoo, A., \& Sharma, K. (2014). A study on determinants of capital structure in India. IIMB Management Review, 26(3), 170-182. DOI: 10.1016/j.iimb.2014.07.009.

Haron, R. (2014). Capital structure inconclusiveness: Evidence from Malaysia, Thailand and Singapore. International Journal of Managerial Finance, 10(1), 23-38. https://doi.org/10.1108/ IJMF-03-2012-0025

Harris, M., \& Raviv, A. (1991). The theory of capital structure. Journal of Finance, 46(1), 297-355. https://doi. org/10.1111/j.1540-6261.1991.tb03753.x

Hausman, J. (1978). Specification Tests in Econometrics. Econometrica, 46(6), 1251-1271. https://doi. org/10.2307/1913827

Hossain, F. (2012). Impact of Firm Specific Factors on Capital Structure Decision: An Empirical Study of Bangladeshi 
Companies. International Journal of Business Research and Management, 3(4), 163-182.

Jensen, M. C. (1986). Agency costs of free cash flow, corporate finance, and takeovers. The American Economic Review, 76(2), 323-329. http://dx.doi.org/10.2139/ssrn.99580

Jensen, M. C., \& Meckling, W. H. (1976). Theory of the firm: Managerial behavior, agency costs and ownership structure. Journal of Financial Economics, 3(4), 305-360. https://doi. org/10.1016/0304-405X(76)90026-X

Kajananthan, R. (2012). Effect of corporate governance on capital structure: Case of the Sri Lankan listed manufacturing companies. Research World, 3(4), 63-71.

Keister, L. A. (2004). Capital Structure in Transition: The Transformation of Financial Strategies in China's Emerging Economy. Organization Science, 15(2), 145-158. DOI: 10.1287/orsc. 1040.0043 .

Miller, M. H. (1977). Debt and taxes. The Journal of Finance, 32(2), 261-275. https://doi.org/10.1111/j.1540-6261.1977.tb03267.x

Modigliani, F. \& Miller, M. H. (1963). Corporate income taxes and the cost of capital: A correction. American Economic Review, 53(3), $433-443$.

Modigliani, F., \& Miller, M. H. (1958). The Cost of Capital, Corporation Finance, and the Theory of Investment: Reply. American Economic Review, 49(4), 655-669.

Myers, S. C. (1977). Determinants of corporate borrowing. Journal of Financial Economies, 9, 147-175. https://doi. org/10.1016/0304-405X(77)90015-0

Myers, S. C. (1984). The capital structure puzzle. The Journal of Finance, 39(3), 574-592. https://doi. $\operatorname{org} / 10.1111 / \mathrm{j} .1540-6261.1984 . t b 03646 . x$

Myers, S. C. (2001). Capital structure. The Journal of Economic Perspectives, 15(2), 81-102. https://doi.org/10.1257/jep.15.2.81

Myers, S. C., \& Majluf, N. S. (1984). Corporate financing and investment decisions when firms have information that investors do not have. Journal of Financial Economics, 13(2), 187-221. https://doi.org/10.1016/0304-405X(84)90023-0

Naveed, A., Zulfqar, A., \& Ishfaq, A. (2010). Determinants of capital structure: A case of life insurance sector of Pakistan. European Journal of Economics, Finance and Administrative Sciences, 1(24), 7-12. https://dx.doi.org/10.2139/ssrn.3400728

Nguyen, C. T., Bui, C. M., \& Pham, T. D. (2019). Corporate capital structure adjustments: Evidence from Vietnam stock exchange market. Journal of Asian Finance, Economics and Business, 6(3), 41-53. https://doi.org/10.13106/jafeb.2019.vol6.no3.41

Nguyen, T. D. C., Dang, D. D., Luong, T. B., \& Nguyen, T. T. T. (2019). Capital structure and performance: Empirical evidence from Vietnam. Journal of Emerging Issues in Economics, Finance and Banking, 8(1), 2802 - 2812.
Nguyen, T. H., \& Nguyen, H. A. (2020). The impact of capital structure on firm performance: Evidence from Vietnam. Journal of Asian Finance, Economics and Business, 7(4), 97-105. https://doi.org/10.13106/jafeb.2020.vol7.no4.97

Ozkan, A. (2002). The determinants of corporate debt maturity: evidence from UK firms. Applied Financial Economics, 12(1), 19-24. https://doi.org/10.1080/09603100110102691

Pandey, I. M. (2002). Capital structure and Market Power Interaction: Evidence from Malaysia. Capital Market Review, 10(1), 23-40. http://dx.doi.org/10.2139/ssrn.322700

Rajan, R. G., \& Zingales, L. (1995). What Do We Know about Capital Structure? Some Evidence from International Data. Journal of Finance, 50(5), 1421-1460. https://doi. org/10.1111/j.1540-6261.1995.tb05184.x

Ross, S. A. (1977). The determinant of financial structure the incentive signaling approach. Bell Journal of Economics, 8(1), 23-40. https://doi.org/10.2307/3003485

Serghiescua, L. \& Văidean, V. L. (2014). Determinant factors of the capital structure of a firm: An empirical analysis. Procedia Economics and Finance, 15, 1447-1457. https://doi. org/10.1016/S2212-5671(14)00610-8

Sheikh, N. A., \& Wang, Z. (2011). Determinants of capital structure an empirical study of firms in manufacturing industry of Pakistan. Managerial Finance, 37(2), 117-133. https://doi. org/10.1108/03074351111103668

Titman, S., \& Wessels, R. (1988). The determinants of capital structure choice, The Journal of Finance, 43(1), 1-19. https:// doi.org/10.1111/j.1540-6261.1988.tb02585.x

Tran, H. S., \& Tran, V. H. (2008). Capital structure and business performance of companies listed on the Ho Chi Minh Stock Exchange. Journal of Economics and Development, 218(12), $36-41$.

Vatavu, S. (2015). The impact of capital structure on financial performance in Romanian listed companies. Rrocedia Economics and Finance, 32(2015), 1314-1322. https://doi. org/10.1016/S2212-5671(15)01508-7

Voulgaris, F., Asteriou, D., Agiomirgianakis, G. (2004). Size and determinants of capital structure in the Greek manufacturing sector. International Review of Applied Economics, 18(2), 247-262. https://doi. org/10.1080/0269217042000186714

Vu, T. M. T, Tran, C. Q, Doan, D. T., \& Le, T. N. (2020). Determinants of capital structure: The Case in Vietnam. Journal of Asian Finance, Economics and Business, 7(9), 159-168. https://doi. org/10.13106/jafeb.2020.vol7.no9.159

Williamson, O. E. (1988). Corporate finance and corporate governance. Journal of Finance, 43(3), 567-591. https://doi. org/10.1111/j.1540-6261.1988.tb04592.x 